\title{
BRAND PROMOTION PECULIARITIES
}

\author{
Svitlana Ivanytska ${ }^{*}$, PhD (Economics), Associate Professor \\ Anna Aheicheva**, PhD (Pedagogy), Associate Professor \\ National University «Yuri Kondratyuk Poltava Polytechnic»
}

*ORCID 0000-0002-7111-270X

**ORCID 0000-0003-2184-8820

(C) Ivanytska S., 2021

(C) Aheicheva A., 2021

Стаття отримана редакиією 28.12.2020 p.

The article received by the reduction 28.12.2020.

Introduction. For many people, a brand is just the name and logo (corporate identity) of a company. But in reality, a brand is much more. That is why people often overpay for it (and pay exactly for the brand, not for the quality of the products). When people buy a well-known brand, they pay for prestige, for image, for emotional satisfaction.

Branding is a powerful marketing communication tool that generates demand and stimulates sells. The brand regulates customer behavior, creates a stable favorable image of the company and product.

In the modern marketing system the central place is given to the formation and promotion of brands.

Advertising promote brands campaigns have their own characteristics. When promoting a company, business owners strive to increase its awareness, image and ratings, as well as indicate positioning.

Analysis of recent research sources and publications. Currently the degree of knowledge of the theory and practice of brand promotion is confirmed by many scientific papers.

A lot of material has been published on general issues of branding, as well as on the formation and promotion of brands, which are presented in detail in the works by such well-known foreign and Ukrainian authors in this area as: Aaker D. A. [1], Joachimsthaler E. [1], Kapferer J.-N. [2], Bastien V.[2], O'Guinn T.[3], Allen C. [3], Semenik R. J. [3], Chatterjee S. [4], Vinod Malshe A. [4], Heath T. B. [4], Hofer K. M. [5], Ho C.-H. [6], Chiu K.-H. [6], Chen H. [6], Papazafeiropoulou A. [6], Vogel A. T. [7], Watchravesringkan K. [7], Bohoiavlenskyi O. V. [8], Polishchuk T. [9], Ukolova A. [10], Tanasiichuk A. [11], Sirenko S. [11], Pnevskyi V. [11], Kotler P., Kakodei A., Larina Ya.

Nevertheless, the analysis of existing publications according the topic under study indicates that such an important issue as brand promotion is insufficiently studied. This is what determined the choice of the research topic.

Background. Building brand awareness is a critical component of any marketing effort.

One of the hardest aspects of marketing is designing effective campaigns that will actually give the best positive results. Brand promotion requires a lot of attention and planning, which can make it a difficult concept for many people.

So, the current direction of scientific research is the latest approaches, techniques and technologies for brand promotion.

The purpose of the article is to study brand promotion peculiarities in order to increase and strengthen its reputation.

Results. A brand is a complex of ideas, thoughts, associations, impressions, emotions, various characteristics about the corresponding product, service, company, which are in the mind of a buyer.

A large number of buyers choose to buy a well-known brand. The reason for this is that they have come across it many times and heard people praise and recommend it.

Brand promotion is a set of activities aimed at informing, persuading, influencing, promoting and recognizing, as well as finding a target audience and bringing a brand to the market.

All this affects the decision-making process by consumers when choosing a particular brand. 
Brand promotion helps to leave a lasting impression of the brand in the mind of a consumer. Brand promotion builds customer confidence and makes them believe that the quality of the product or service that the brand represents is the best choice available in the market.

The process of brand promotion includes: marketing a brand name and logo, making souvenirs, placing on various media, releasing videos, advertising layouts, online announcements and much more.

Building a strong brand requires consistency in the products or services that are provided and in interaction with consumers. The main goal of all this is to make consumers of the brand feel that it can provide exactly what they need.

Brand promotion is beneficial for both business and consumer and society in general.

It helps businesses build a long-term brand.

This gives the consumer information about the reputation, quality, quantity, price, benefits and availability of products.

For society, it enables new jobs, activation of mass production, reduces the price of goods and leads to higher sales of the branded product, in turn, it means higher tax revenues for the government and, as a result, ensures economic growth.

The most popular methods used to promote brands:

1. Advertising is a way of spreading brand information through traditional media (newspapers, magazines, television, etc.) or new media (social media, blogs, etc.). Media coverage of these events, in turn, increases the authority and public image of a brand.

Advertising plays a very important role in promoting products in rapidly evolving markets and is seen as one of the main brand building tools. The process is very convenient and economical, but it lacks an individual approach.

2. Personal selling is that it involves personal communication and a separate approach to each consumer. Sellers, therefore, after the transaction, receive feedback from the buyer. But there is a definite disadvantage to personal selling, which is that it is a time consuming method.

3. Packaging. Nowadays, the perception and appearance of a product is very important. The better the product looks, the faster it sells. Consumers are ready to pay a higher price for appearance and convenience. When a product is packaged in a pretty wrapper, it does not only help to identify it, but also builds a brand image. Custom-made packaging is a great way to make your brand memorable.

4. A $360^{\circ}$ campaign is a comprehensive marketing approach that attempts to reach consumers at all levels of communication channels to promote a brand. Successful campaigns will maximize sales.

5. Online brand promotion is a method of promoting a brand on various social platforms by using the power of the Internet to reach a wider audience of users.

Considering the statistics of Internet users nowadays, online brand promotion has become on an equal basis with traditional ones. There are even some advantages of online branding, such as: lower cost compared to traditional; wide audience; targeted promotion; easy measurement of results and more.

Next, let's look at the main ways to promote a brand.

Website creation. First of all, you need to create content that is interesting and educational, so people know who you are and what you can offer them. This process can be seen as a way to lure customers because when they are ready to buy, they will be looking at your brand and not your competitors. Research displays that most of the visitors who come to your site are not ready to make a purchase. And therefore, in order for the purchase to take place, you need to focus on SEO (search engine optimization) strategies.

Search engine optimization. When you consider that your company is not world famous, people will not know about your brand and what you have to offer. That is, without the right popularity, you will not achieve what you would like. The solution is to focus on SEO and find the right keywords that your customers will use to find your product or service online.

That is, an effective search strategy involves a number of steps, from building a keyword strategy to doing more detailed keyword research, optimizing your site's architecture and performance, to building links to your site.

Brand promotion campaigns through SEO-optimization imply the use of well-thought-out PR articles that will combine both high utility for the reader and competent positioning of a brand or company. This allows you to convey to the consumer the right thoughts in the right form, increase authority and image.

Social networks. Social media plays an important role in the e-commerce world. Thanks to them, you have a unique opportunity to reach as many people as possible who will see your brand, and as a result, get more potential customers. 
Studies have shown that the majority of Ukrainians use social networks on a daily basis (Facebook, Instagram, Twitter and many others), and they are the most famous of the social media platforms. The difference between them is the uniqueness of the interaction. This means you can focus on the network that works best for you - instead of trying to master them all at once.

But don't just use social media to sell your products. In this case, no one will follow your brand. Don't forget about the social side of social media.

Live broadcast. Nowadays, social media platforms allow their users to participate in live streaming. For example, on YouTube and Facebook, you can tell your unique story and build your audience in real time.

Tell a story. In order to attract an Internet audience, you need to tell a story, because it is well known that customers react to various emotions: delight, surprise, joy, sadness or anger. Having a page that tells your story is not new. But most of the pages are boring enough. Liven it up a bit. Create one page dedicated to your story, goals, and mission, and dedicate another page to your team. That is, you need to connect with your target audience, show your unique brand identity - especially if you are cheerful, outspoken, outrageous or magical. It is this combination of factors that will make your brand memorable.

Creation of valuable content. Google has many ways to share products and services: videos, podcasts, infographics, blogs, and other media. This method of brand marketing will not only generate traffic and increase revenue, but it will also make you a visible authority on the topic.

Blogging. By discussing things that are happening in your industry, you provide an educational and informational blog and thus gain people's trust. This is exactly what blogging is all about, the overall purpose of which is to educate and inform to the point where readers trust enough to buy a brand. But don't write a wordy message, because even regular visitors can stop reading. Therefore, successful brand advertising revolves around messages with as few words as possible.

Email. Creating an email list is not an easy task as the slogan on your web page with the text: "Subscribe to our mailing list and stay updated with all our latest news" does not sound very convincing. Instead, you can think of another way to get your email address. For example: "Enter your email address and get $10 \%$ off your first purchase.” This way you get an email address and increase your chances of selling an item. The email format strengthens relationships with subscribers and leads to conversions and sales.

The LinkedIn Publishing Platform is a site that can become a stream for a multitude of users if it is constantly engaged. It is designed as a professional tool for employees and employers, but it has gained extraordinary popularity lately. This is largely due to the fact that professionals share information, services, and products that they find useful or interesting on it.

Prizes. Everyone knows that customers feel more valuable and motivated when they receive free gifts. In other words, you need to build brand awareness and establish contact with potential customers by offering small gifts, such as fridge magnets, pens, badges, key rings, notepads. Also, you can advertise and promote products by offering discounts or samples in exchange for honest reviews.

Infographics. Brands need a way to make their content and digital presence more vibrant, engaging and enticing. Design is very often the main focus for those looking to make a good first impression and establish brand awareness. Many people pay attention to a good data set. Very often this data is boring and therefore brands that are able to visually display this data in interesting formats can earn a large number of links from those who find it interesting. Various interactive data formats such as maps, graphs and charts can be considered. These elements can be programmed in various ways. And every time they are rendered in an interesting and interactive format, your site will be wildly popular. Exciting market data is best reflected in a colorful and vibrant way. Another bonus is the fact that users are more inclined towards this brand building tool as it instills faith and trust. Infographics are easy to post and share on social media, and easy to read.

Car wraps. Car wraps are custom-designed designs that can cover the entire car or part of it, bringing a lot of attention to your brand. This way, you allow people to become familiar with your brand, slowly but surely.

Networking events. They are similar to corporate parties, trade shows and other similar examples that are perfect for building brand awareness. These events will not only allow you to get out of the office and chat with real people, but also introduce potential customers who will hear more about various future brands. Instead of taking these steps with the intention of selling a service, you need to open your mind to the prospect of self-education, researching success stories, and making contact with others on a personal level.

Offline advertising. Placing advertising banners in an offline environment is an integral part of a company's positioning. It can be not only advertising on billboards, but also clips on television or radio inserts. 
People are constantly arguing about which is more profitable, offline or online advertising. There is no need to single out any one channel, since the effectiveness of each of them will be individual for each project.

Promotions. This is a whole list of all kinds of events and tools that provide your company with increased interest from the consumer, increase in recognition and loyalty of real and potential customers.

Promotions include various actions, contests, free seminars, exhibitions, providing consumers with a trial version of the product, interviews on TV, radio, etc. Promotions can be used both in online promotion and in a live environment (offline). Promotions are an inexpensive way to promote your brand.

Loyalty programs. This can include various activities to motivate people to come back to you again and again. Discounts have always motivated people. People love a benefit, so give it to them. We need to think over a competent coupon-discount system, arrange sales, promotions, contests, quizzes, etc.

Free trial versions of the product. Don't be afraid to give your audience the opportunity to try your product for free. After all, most people want to check first and only then pay money.

Free samples not only motivate people to make complete purchases, but also show you your best side. You are not only concerned with money and profits, but also with customer satisfaction. You make sure that they like the product, so you give them this opportunity.

Strong branding. It is very important to separate your brand from others even when you are just starting out. To get your name noticed and your goal achieved, choose a logo that will highlight your product and connect to your target audience. It's also important to consider using colors, styles, and shapes that mean something to you, as every single detail will work to create who you are.

Conclusions. Brand promotion is creating consumer confidence in a product. Today, it is less necessary to prove the importance and effectiveness of branding. The use of Internet resources will allow the brand to reach a wider audience through social media communication and globalization. Branding on the Internet is developing rapidly, which means that companies that start using it earlier will be significantly ahead of their competitors, and thus will be able to increase their profits faster.

So, brand promotion campaigns are different. Some are aimed at increasing popularity, others contribute to positioning, and still others help to capture the market.

All channels and promotion methods can be used at once, or just one. It all depends on the goals, preferences and budget.

Branding takes a lot of effort, money and time, but it can dramatically increase a product's sales. And as soon as a brand takes a leading position in the market and its identity is established, then a long-term result will be achieved. That's why, put in as much effort as possible when hiring marketers who can help you to create your desired brand image.

\section{REFERENCES:}

1. David A. Aaker and Erich Joachimsthaler (2009). Brand Leadership: Building Assets in an Information Economy. Pocket Books, p. 368

2. Jean-Noel Kapferer and Vincent Bastien (2013). The Luxury Strategy: Break the Rules of Marketing to Build Luxury Brands. Kogan Page.

3. Thomas O'Guinn, Chris Allen and Richard J. Semenik (2011). Advertising and Integrated Brand Promotion. Cengage Learning, p. 734.

4. Subimal Chatterjee, Ashwin VinodMalshe and Timothy B.Heath (2010). The effect of mixed versus blocked sequencing of promotion and prevention features on brand evaluation: The moderating role of regulatory focus. Journal of Business Research, Vol. 63, Issue 12, p. 1290-1294. doi:https://doi.org/10.1016/j.jbusres.2009.09.003

5. Hofer, K.M. (2015). International brand promotion standardization and performance, Management Research Review, Vol. 38, No. 7, p. 685-702. doi: https://doi.org/10.1108/MRR-06-2013-0136

6. Ho, C.-H., Chiu, K.-H., Chen, H. and Papazafeiropoulou, A. (2015). Can internet blogs be used as an effective advertising tool? The role of product blog type and brand awareness. Journal of Enterprise Information Management, Vol. 28 No. 3, pp. 346-362. doi: https://doi.org/10.1108/JEIM-03-2014-0021

7. Vogel, A.T. and Watchravesringkan, K. (2017). Consumer evaluations of trend imitation: brand equity, consumer attitudes and preference. Journal of Product \& Brand Management, Vol. 26 No. 5, pp. 516-527. doi:https://doi.org/10.1108/JPBM-07-2016-1257

8. Bohoiavlenskyi O.V. (2018). National branding as a way of improving the competitiveness of Ukrainian products. Infrastruktura rynku [Market Infrastructure], No. 17, pp. 11-17. 
9. Polishchuk, T. (2009). Perspective directions of development of successful brands in Ukraine. Aktualni problemy ekonomiky [Actual problems of economics], No 7 (97), pp. 129-137.

10. Ukolova, A. (2012). Essence of branding and its use by domestic enterprises. Upravlinnia rozvytkom [Management development], No 1, pp. 128-130.

11. Tanasiichuk A., Sirenko S. and Pnevskyi V. (2020). Formation of a brand promotion strategy using digital marketing. Skhidna Yevropa: ekonomika, biznes ta upravlinnia [Eastern Europe: economy, business and management], No 1(24), pp. 161-167. doi:https://doi.org/10.32782/easterneurope.24-23

\section{УДК 659.12:005.336-021.321}

JEL M30

Іваницька Світлана Богданівна, кандидат економічних наук, доцент. Агейчева Анна Олександрівна, кандидат педагогічних наук, доцент, декан гуманітарного факультету. Національний університет «Полтавська політехніка імені Юрія Кондратюка». Особливості просування бренду. Досліджено особливості просування бренду. Просування бренду - це комплекс заходів, спрямованих на інформування, переконання, вплив, розкрутку та впізнаваність, а також на пошук цільової аудиторії й виведення на ринок бренду. Визначено, що процес просування бренду включає в себе: маркетинг фірмового найменування і логотипу, виготовлення сувенірної продукції, розміщення на різних носіях, випуск відеороликів, макети для реклами, анонси в Інтернеті та багато іншого. Розглянуто найпопулярніші методи, які використовуються для просування брендів, такі як: реклама, особистий продаж, упаковка, кампанія $360^{\circ}$, просування бренду в Інтернеті. Доведено, що способами просування бренду є: створення сайту, оптимізація систем пошуку, соціальні мережі, трансляція в прямому ефірі, розповідь історії, створення цінного контенту, ведення блога, електронна пошта, LinkedIn Publishing Platform, призи, інфографіка, автомобільні обгортки, мережеві заходи, офлайнреклама, промоакції, програми лояльності, безкоштовна роздача пробної версії продукту, сильний брендинг. У результаті дослідження визначено, що просування бренду - це створення довіри споживачів до продукту. Кампанії з просування бренду різноманітні. Одні націлені на збільшення популярності, другі сприяють позиціонуванню, треті допомагають захопити ринок. Можна використовувати всі канали і способи просування відразу, а можна застосовувати якийсь один. Усе залежить від цілей, які потрібно досягнути, переваг та бюджету. Брендинг вимагає багато зусиль, грошей і часу, але він може різко збільшити обсяг продажів продукту.

Ключові слова: бренд, брендинг, просування, реклама, цільова аудиторія, фірмова ідентичність, контент, інфографіка.

\section{UDC 659.12:005.336-021.321}

JEL M30

Ivanytska Svitlana, $\mathrm{PhD}$ (Economics), Associate Professor. Aheicheva Anna, $\mathrm{PhD}$ (Pedagogy), Dean of Faculty of Humanities. National University "Yuri Kondratyuk Poltava Polytechnic». Brand Promotion Peculiarities. The brand promotion peculiarities are studied. It has been determined that the process of brand promotion includes: marketing a brand name and logo, making souvenirs, placing on various media, releasing videos, layouts for advertising, announcements on the Internet and much more. Used methods to promote brands are considered, such as: advertising, personal selling, packaging, $360^{\circ}$ campaign, brand promotion on the Internet. The ways to promote a brand have been proven to be: website building, search engine optimization, social media, live streaming, storytelling, creating valuable content, blogging, email, LinkedIn Publishing Platform, prizes, infographics, car wraps, networking events, offline ads, promotions, loyalty programs, free trial product giveaways, strong branding. As a result of the study, it was found that brand promotion is the creation of consumer confidence in a product.

Key words: brand, branding, promotion, advertising, target audience, corporate identity, content, infographics. 